\title{
Staggered Price Setting and Real Rigidities
}

\author{
Michael T. Kiley* \\ Division of Research and Statistics \\ Federal Reserve Board
}

August 1997

\begin{abstract}
This paper emphasizes the notion that model features that contribute to endogenous price rigidity under staggered price setting lower the elasticity of marginal cost with respect to output, and these same model features tend to generate equilibrium indeterminacy, or "sunspot fluctuations", under price flexibility. Using this insight, staggered price setting is shown to imply persistent output responses to monetary shocks for certain parameterizations of one and two sector models with small increasing returns or countercyclical markups, and other model features that would contribute to persistence are discussed.
\end{abstract}

JEL Codes: E32, E10, E31

keywords: nominal price rigidity, indeterminacy

"Address: Division of Research and Statistics, Federal Reserve Board, Washington, DC 20551, phone: (202)4522448, e-mail: mkiley@frb.gov. This paper contains some material from an earlier paper titled "Staggered Price Setting, Partial Adjustment, and Real Rigidities". I would like to thank Chris Erceg, Gary Hansen, Jinill Kim, and workshop participants at the Federal Reserve Board, UCLA, the 1997 North American Summer Meetings of the Econometric Society, and the 1997 Monetary Economics program at the NBER Summer Institute for helpful comments. The views expressed herein are solely the author's, and do not reflect those of the Federal Reserve Board or its staff. 


\section{Introduction}

"Why do shifts in demand facing firms lead largely to adjustment in output rather than in prices... Or put another way, why is the output supply function so flat?"

Blanchard and Fischer (1989), p. 463.

Recent research has incorporated nominal price rigidity into otherwise "typically" calibrated dynamic general equilibrium economies (or "real business cycle" type models). In contrast to the wellknown result in Taylor (1980), such models do not generate substantial price rigidity beyond the exogenously imposed period of nominal price stickiness (i.e., a large Taylor contract multiplier), and hence have trouble generating persistent responses of output to monetary policy shocks. In effect, such models have a steep "output supply" function, and are incapable of answering the challenge posed above by Blanchard and Fischer.

Actually, this result is not particularly surprising; Blanchard and Fischer (1989), Ball and Romer (1990), and Romer (1996) argue that basically neoclassical models are incapable of generating flat supply sides. The argument is that neoclassical models' reliance on constant returns to scale, intertemporal substitution in labor supply, and a small role for imperfect competition guarantees strongly procyclical marginal cost and essentially constant desired markups, a combination leading to strong incentives to adjust prices in response to an output expansion. These authors then suggest a laundry list of "new-Keynesian" model features that help to flatten the supply side of the model, including labor market imperfections, increasing returns to scale, countercyclical markups, credit market imperfections, and multiple equilibria. The common thread in each of these suggestions is that they either lower the elasticity of marginal cost with respect to output, or lead to lower desired markups during output expansions, and therefore decrease incentives for price adjustment in response to shifts in aggregate demand. This flatness is termed real rigidity throughout the new-Keynesian literature. ${ }^{1}$ Unfortunately, many of the models in the literature emphasizing these new-Keynesian features are highly stylized, and hence difficult to incorporate into dynamic general equilibrium (DGE) economies.

This paper illustrates the ability of several of these new-Keynesian real rigidities to enhance the Taylor contract multiplier and deliver persistent output responses to monetary policy shocks. In particular, DGE models with staggered price setting and increasing returns or countercyclical markups are presented in sections 3 through 5, and persistent output responses arise for certain parameterizations that impart "flatness". In fact, certain parameterizations delivering persistent output responses seem plausible. 
A key insight in this paper is the recognition that the flatness required for persistence in response to monetary shocks also plays an important role in another "Keynesian" approach to fluctuations in dynamic general equilibrium economies - models with sunspot fluctuations. For example, a flat marginal cost schedule enhances the persistence of output responses to monetary policy shocks in a staggered price setting model because rising costs place less dampening pressure on output movements if marginal cost responds weakly to output movements. Similarly, a flat marginal cost schedule enhances the ability of a model to allow fluctuations due to self-fulfilling expectations, or sunspot fluctuations, because the absence of output dampening through rising costs removes an important barrier to output movements. The early models of sunspot fluctuations due to strongly increasing returns (Benhabib and Farmer (1994)) are a good example. The parallel requirement of "flatness" in both sticky price and sunspot models suggests that incorporation of features emphasized in the DGE literature on sunspot fluctuations will enhance the persistence of output responses to monetary policy shocks in sticky price DGE models; sticky price versions of the models in Benhabib and Farmer $(1994,1996)$ and Gali (1994), which were designed to illustrate the possibility of sunspot fluctuations, confirm this intuition.

Before turning to DGE models, section 2 develops a simple optimizing business cycle model that abstracts from capital accumulation to illustrate the central role the curvature of marginal cost plays in price rigidity. As emphasized in the static analysis of Ball and Romer (1990), price stickiness only occurs when marginal cost is relatively acyclical. The lack of output dampening also leads to "near equilibrium indeterminacy"; when marginal costs do not rise in response to an output movement, the equilibrium level of output is indeterminate because rising costs place no pressure on output to return to any particular equilibrium level. Sections 3 through 5 use the notion that the real rigidities emphasized in the new-Keynesian literature on sticky prices are features conducive to indeterminacy to explore whether features conducive to indeterminacy in DGE models (as discussed in, for example, Benhabib and Farmer (1997)) enhance the persistence of output responses to monetary policy shocks in sticky price models.

Two lines of work are very closely related to the analysis of this paper. First, in this paper, price rigidity is exogenous as is typical in new-Keynesian and sticky price DGE models, and the rational expectations equilibrium is unique under sticky prices for the parameter values considered. However, the intuition is similar to the endogenous equilibrium selection price rigidity models of Farmer (1991) and especially Beaudry and Devereux (1995). In these models, stationary sunspot equilibria exist for the chosen parameter values. By making prices a predetermined variable (i.e., set 
one period in advance), a unique equilibrium results. Intuitively, prices can act as a predetermined variable because, although desired price markups are constant, the increasing returns necessary for sunspots yield acyclical marginal cost, and hence predetermined prices are consistent with firm optimization.

Other closely related analyses are those of Kimball (1995), Chari, Kehoe, and McGrattan (1996), Dotsey, King, and Wolman (1997), Erceg (1997), and Goodfriend and King (1997). Chari, Kehoe, and McGrattan (1996) illustrate the failure of the basic "neoclassical" dynamic general equilibrium economy to generate a substantial Taylor contract multiplier, as expected from the discussion of the new-Keynesian literature above. Kimball (1995) introduces several "real rigidities", emphasizing countercyclical desired markups as discussed in section 5. The analysis herein differs from each of these previous authors by making the observation that model features conducive to endogenous price rigidity under staggered price setting are those which tend to generate sunspot fluctuations under price flexibility; this observation opens a host of avenues for increasing the "Taylor contract multiplier", as discussed in section 6. A second important difference is the explicit consideration of staggered price setting, in contrast to the partial adjustment model used in Kimball (1995) and Goodfriend and King (1997). Partial adjustment assumes a great deal more exogenous price rigidity than actual staggering, and hence is not the best model for focusing on endogenous rigidity. ${ }^{2}$ Finally, in sections 3 through 5 monetary policy is specified through a nominal interest rate rule, as seems reasonable given central bank practices. This type of monetary policy renders the parameters of the money demand function unimportant for the persistence properties of staggered price setting, in contrast to the important role money demand plays in Chari, Kehoe, and McGrattan (1996), Dotsey, King, and Wolman (1997), and Erceg (1997). ${ }^{3}$

\section{Staggered Price Setting in an Optimizing IS/LM Model}

In this section, the staggered price setting model is introduced in a simple optimizing IS/LM model (McCallum and Nelson (1997)) to illustrate the model features important for endogenous persistence, and how typical dynamic general equilibrium models lack these features.

\section{Consumers}

Consumers have preferences over consumption of the final good $(\mathrm{C})$ and labor $(\mathrm{N})$ that are given by the utility function $U=\sum_{i \geq 0} \beta^{i}\left\{\log \left(C_{t+i}\right)-N_{t+i}^{1+s} /(1+s)\right\}$. Consumers receive labor income, own the firms (and receive any profits), and invest in real bonds, so their budget constraint is given by 


$$
\mathrm{C}_{\mathrm{t}}+\mathrm{B}_{\mathrm{t}+1}=\mathrm{W}_{\mathrm{t}} \mathrm{N}_{\mathrm{t}}+\left(1+\mathrm{r}_{\mathrm{t}}\right) \mathrm{B}_{\mathrm{t}}+\Pi_{\mathrm{t}}
$$

where $\mathrm{W}$ is the real wage, $\Pi$ is profits, $\mathrm{B}$ is bond holdings, and $\mathrm{r}$ is the real interest rate. Utility maximization then implies the familiar equilibrium conditions:

$$
\begin{aligned}
& 1 / \mathrm{C}_{\mathrm{t}}=\beta \mathrm{E}_{\mathrm{t}}\left\{1 / \mathrm{C}_{\mathrm{t}+1}\left[1+\mathrm{r}_{\mathrm{t}+1}\right]\right\}, \\
& \mathrm{C}_{\mathrm{t}} \mathrm{N}_{\mathrm{t}}^{\mathrm{s}}=\mathrm{W}_{\mathrm{t}} .
\end{aligned}
$$

These conditions simply equate the marginal utility of consumption today with the discounted marginal utility from postponing consumption until next period, and the marginal rate of substitution between leisure and consumption to the real wage (which represents the price of leisure).

Note that all output of the final good is consumed $(\mathrm{Y}=\mathrm{C})$, so log-linearization of the above first order conditions (with lower case denoting the log deviation of the corresponding variable from its steady state value) yields

$$
\begin{aligned}
& \mathrm{y}_{\mathrm{t}}=\mathrm{E}_{\mathrm{t}}\left\{\mathrm{y}_{\mathrm{t}+1}-\mathrm{r}_{\mathrm{t}+1}\right\}, \\
& \mathrm{y}_{\mathrm{t}}=-\mathrm{sn}_{\mathrm{t}}+\mathrm{w}_{\mathrm{t}} .
\end{aligned}
$$

\section{Final Goods}

The final goods sector is competitive (i.e., firms are price takers and adjust nominal prices in each period). The production function for final goods output $(\mathrm{Y})$ takes intermediate goods (distributed over $(0,1))$ as inputs $\left(\mathrm{Y}_{\mathrm{i}}\right)$ :

$$
\mathrm{Y}=\left[\int_{0}^{1} \mathrm{Y}_{\mathrm{i}}^{\theta} \mathrm{di}\right]^{1 / \theta}, 0<\theta<1 .
$$

Cost minimization by final goods firms yields the demand functions for intermediate goods

$$
\mathrm{Y}_{\mathrm{i}}=\mathrm{Y}\left(\mathrm{X}_{\mathrm{i}} / \mathrm{P}\right)^{-1 /(1-\theta)}
$$

where $X_{i}$ is the price of good $i$, and $P$ is the aggregate price index $\left(=\left[\int_{0}^{1} X_{i}^{\theta /(\theta-1)} d i\right]^{(\theta-1) / \theta}\right)$. These demand functions for intermediate goods are of the constant elasticity type, giving market power to the monopolistically competitive intermediate goods producers.

\section{Intermediate Goods}

Intermediate goods firms will set nominal prices according to a rule discussed below, and meet demand (from the previous subsection) at the posted price. Firms produce output according to the production function

$$
\mathrm{Y}_{\mathrm{it}}=\mathrm{N}_{\mathrm{it}}{ }^{\mathrm{a}} \text {, }
$$

where "a" governs returns to scale. Note that zero profits in the steady state requires increasing returns to scale (since monopolistic competition implies price greater than marginal cost, average cost 
must exceed marginal cost for zero profits). Cost minimization yields

$$
\mathrm{W}_{\mathrm{t}}=\mathrm{aMC}_{\mathrm{it}} \mathrm{Y}_{\mathrm{il}} / \mathrm{N}_{\mathrm{it}} \text {, }
$$

where real marginal cost MC (or the inverse of the price-marginal cost markup) is the lagrange multiplier on the production function in the minimization. Taking logs of the production function and the cost minimization condition (and eliminating constants) yields ${ }^{4}$

$$
\begin{aligned}
& \mathrm{w}_{\mathrm{t}}=\mathrm{mc}_{\mathrm{t}}+\mathrm{y}_{\mathrm{t}}-\mathrm{n}_{\mathrm{t}}, \\
& \mathrm{y}_{\mathrm{t}}=\mathrm{an}_{\mathrm{t}} .
\end{aligned}
$$

Solving (2.2), (2.3) and (2.4) for employment, wages, and marginal cost as functions of output yields

$$
\begin{aligned}
& \mathrm{n}_{\mathrm{t}}=\mathrm{y}_{\mathrm{t}} / \mathrm{a}, \\
& \mathrm{w}_{\mathrm{t}}=(\mathrm{s}+\mathrm{a}) \mathrm{y}_{\mathrm{t}} / \mathrm{a}, \\
& \mathrm{mc}_{\mathrm{t}}=[1+\mathrm{s}] \mathrm{y}_{\mathrm{t}} / \mathrm{a}=\mathrm{by}_{\mathrm{t}} .
\end{aligned}
$$

Equation (2.7) reveals the unsurprising conclusion that the elasticity of marginal cost with respect to output (b) is determined by returns to labor in production and the elasticity of labor supply $(b=$ $(1+s) / a)$.

\section{Price Adjustment Rule}

The staggered price setting model is a two period specification, inspired by Taylor (1980) and following the treatment of Blanchard and Fischer (1989). Firms have market power and set prices (X) for two periods at the start of period $t$; in particular, firms choose the nominal price $\mathrm{X}_{\mathrm{it}}$ that maximizes

$$
\sum_{j=0}^{1} E_{t}\left\{\beta^{j} \Lambda_{t+j}\left(X_{i t} Y_{i t+j}-P_{t+j} \Gamma\left(Y_{i t+j}\right)\right)\right\},
$$

where $\Gamma\left(\mathrm{Y}_{\mathrm{it}+\mathrm{j}}\right)$ is the cost function of firm i (determined from the minimization problem above), and the firm's discount factor $\beta^{\mathrm{j}} \Lambda_{\mathrm{t}+\mathrm{j}}$ incorporates both the subjective dscount factor of consumers (who own the firms), and the marginal utility of income in period $t+j\left(\Lambda_{t+j}=1 / C_{t+j}\right)$. The first order condition (given the demand function $Y_{t}{ }^{i}$ above) yields

$$
\mathrm{X}_{\mathrm{it}}=\left[\sum_{\mathrm{j}=0}{ }^{1} \mathrm{E}_{\mathrm{t}}\left\{\beta^{\mathrm{j}} \Lambda_{\mathrm{t}+\mathrm{j}} \mathrm{MC}_{\mathrm{it}+\mathrm{j}} \mathrm{Y}_{\mathrm{it}+\mathrm{j}} \mathrm{P}_{\mathrm{t}+\mathrm{j}}\right\}\right] / \theta\left[\sum_{\mathrm{j}=0}{ }^{1} \mathrm{E}_{\mathrm{t}}\left\{\beta^{\mathrm{j}} \Lambda_{\mathrm{t}+\mathrm{j}} \mathrm{Y}_{\mathrm{it}+\mathrm{j}}\right\}\right],
$$

which shows that nominal prices chosen by a firm at time $t$ are a markup (1/ $\theta)$ over nominal marginal cost over the period for which the price will hold. Log-linearizing for $\beta \approx 1$ yields the equation for the $\log$ of nominal prices set in period t used in Blanchard and Fischer (1989) and Chari, Kehoe, and McGrattan (1996),

$$
x_{t}=1 / 2 E_{t}\left[p_{t}+m c_{t}+p_{t+1}+m_{t+1}\right] .
$$


The equation for the price level (p) is given by the average of outstanding prices,

$$
\mathrm{p}_{\mathrm{t}}=1 / 2\left(\mathrm{x}_{\mathrm{t}}+\mathrm{x}_{\mathrm{t}-1}\right) \text {. }
$$

\section{Money}

To close the model and examine the behavior of prices and output in response to monetary shocks requires specification of how monetary shocks enter the model. For the purpose of this introductory section, money demand is given by the quantity equation,

$$
\mathrm{m}_{\mathrm{t}}=\mathrm{y}_{\mathrm{t}}+\mathrm{p}_{\mathrm{t}} \text {. }
$$

The nominal money supply $(\mathrm{m})$ is a random walk.

\section{Solution}

The model considered above implies that real marginal cost is related to output by (2.7), which implies (in conjunction with (2.8), (2.9), and (2.10)) that output and the price level under staggered price setting are given by

$$
\begin{aligned}
& \mathrm{p}_{\mathrm{t}}=\mathrm{kp}_{\mathrm{t}-1}+1 / 2(1-\mathrm{k})\left(\mathrm{m}_{\mathrm{t}}+\mathrm{m}_{\mathrm{t}-1}\right), \\
& \mathrm{y}_{\mathrm{t}}=\mathrm{ky}_{\mathrm{t}-1}+1 / 2(1+\mathrm{k})\left(\mathrm{m}_{\mathrm{t}}-\mathrm{m}_{\mathrm{t}-1}\right),
\end{aligned}
$$

where $\mathrm{k}=\left(1-\mathrm{b}^{1 / 2}\right) /\left(1+\mathrm{b}^{1 / 2}\right){ }^{5}$

In the staggered price setting model, the parameter $\mathrm{k}$ indexes endogenous price stickiness. For $\mathrm{k}$ near 1, prices adjust very slowly and the output effects of nominal aggregate demand shocks are long-lived. For k near zero, prices basically adjust completely to their long run level after the exogenously imposed periods of price stickiness have expired. In order for endogenous price stickiness to arise, marginal cost must be relatively acyclical (as b near zero implies $\mathrm{k}$ near 1 ). This simply illustrates the straightforward notion that rising costs dampen output fluctuations. However, note that under constant returns, the elasticity of marginal cost with respect to output (b) is always greater than one, implying $\mathrm{k}<0$; staggering in this optimizing IS/LM model cannot deliver persistent output responses because marginal costs are strongly procyclical, implying rapid price adjustment. This is true even when labor supply is very elastic ( $(s \approx 0)$. Chari, Kehoe, and McGrattan (1996) conclude that staggering is incapable of generating persistence based on models similar to that of this section.

\section{On the Relationship Between "Real Rigidities" and Indeterminacy}

The degree of price rigidity is decreasing in b; this result is intuitive, as it simply states that 
prices adjust more when marginal cost rises more quickly, and these rising costs serve to dampen output fluctuations. The formula for b suggests that low labor supply elasticities and increasing returns to labor are good candidates for lowering $\mathrm{b}$ and raising endogenous price rigidity. For example, Ball and Romer (1990) emphasize the possibility that efficiency wages raise the labor supply elasticity, thus lowering $\mathrm{b}$ and raising price rigidity.

A link between real rigidities and factors conducive to equilibrium indeterminacy relies on the fact that real rigidities tend to lessen the dampening of output fluctuations. Equilibrium indeterminacy similarly requires that the dampening influence of rising costs be lessened. For example, consider the extreme case of a model which results in $b=0$ in (2.7). ${ }^{6}$ In this case, the desired price markup never deviates from its steady state value $(\mathrm{mc}=0)$, revealing that the equilibrium level of employment and output are indeterminate. The aggregate demand equation (2.7) allows the money supply (m) to act as a "sunspot" variable, and output equals nominal aggregate demand $(y=m)$; the equilibrium level of output is indeterminate, and hence output simply follows aggregate demand.

The flexible price version of the model with $b=0$ similarly allows "sunspot fluctuations". Under price flexibility, firms desire a constant markup $(\mathrm{mc}=0)$. With $b=0$, markups are always at their steady state value, and the equilibrium conditions are satisfied for certain "sunspot" processes.

A literature review also emphasizes the links between sticky price models and sunspot models. The new-Keynesian notion of real rigidity is often associated with low labor supply elasticities, increasing returns or externalities, and countercyclical markups (Ball and Romer (1990)). These same features conducive to price rigidity in the new-Keynesian literature play a central role in research on indeterminacy or "sunspot fluctuations", because these type of fluctuations similarly require that output movements not be strongly dampened by rising costs. For work on sunspots emphasizing low labor supply elasticities, increasing returns, and countercyclical markups, see Benhabib and Farmer (1994,1996), Gali (1994), Rotemberg and Woodford (1995), Schmitt-Grohe (1997), and the survey of Benhabib and Farmer (1997).

\section{A One Sector Dynamic General Equilibrium Model}

The focus now shifts to staggered price setting in standard DGE models with capital accumulation. This focus allows direct comparison to previous work, and raises two questions:

1. Does previous work on sticky prices employ model features that generate persistence under staggered price setting?

2. If the answer to this question is no, can reasonably parameterized DGE models embody 
significant real rigidities, yielding persistence?

\section{Consumers}

Consumers have preferences over consumption of the final good $(\mathrm{C})$ and labor $(\mathrm{N})$ that are given by the utility function $U=\sum_{\mathrm{i} \geq 0} \beta\left\{\log \left(\mathrm{C}_{\mathrm{t}+\mathrm{i}}\right)-\mathrm{N}_{\mathrm{t}+\mathrm{i}}{ }^{1+\mathrm{s}} /(1+\mathrm{s})\right\}$. The primary modification from the previous section is the incorporation of capital accumulation. Consumers own and rent to firms the capital in the economy, and own the firms (and receive any profits), so their budget constraint and capital accumulation equations are given by

$$
\begin{aligned}
& \mathrm{C}_{\mathrm{t}}+\mathrm{I}_{\mathrm{t}}+\mathrm{B}_{\mathrm{t}+1}=\mathrm{W}_{\mathrm{t}} \mathrm{N}_{\mathrm{t}}+\mathrm{U}_{\mathrm{t}} \mathrm{K}_{\mathrm{t}}+\mathrm{I}_{\mathrm{t}}+\left(1+\mathrm{r}_{\mathrm{t}}\right) \mathrm{B}_{\mathrm{t}}, \\
& \mathrm{K}_{\mathrm{t}+1}=\mathrm{I}_{\mathrm{t}}+(1-\mathrm{d}) \mathrm{K}_{\mathrm{t}},
\end{aligned}
$$

where I is investment (of the final good), $\mathrm{W}$ is the real wage, $\mathrm{U}$ is the real user cost of capital, $\Pi$ is profits, $\mathrm{K}$ is capital, $\mathrm{B}$ is real bond holdings, $\mathrm{r}$ is the interest rate on bond holdings, and $\mathrm{d}$ is the depreciation rate. Utility maximization then implies the familiar equilibrium conditions:

$$
\begin{aligned}
& 1 / \mathrm{C}_{\mathrm{t}}=\beta \mathrm{E}_{\mathrm{t}}\left\{1 / \mathrm{C}_{\mathrm{t}+1}\left[\mathrm{U}_{\mathrm{t}+1}+1-\mathrm{d}\right]\right\}=\beta \mathrm{E}_{\mathrm{t}}\left\{1 / \mathrm{C}_{\mathrm{t}+1}\left[1+\mathrm{r}_{\mathrm{t}+1}\right]\right\}, \\
& \mathrm{C}_{\mathrm{t}} \mathrm{N}_{\mathrm{t}}^{\mathrm{s}}=\mathrm{W}_{\mathrm{t}} .
\end{aligned}
$$

Equilibrium requires that output equals consumption plus investment

$$
Y_{t}=C_{t}+I_{t} \text {. }
$$

\section{Final Goods}

The treatment of final goods is identical to that in the previous section. The final goods sector is competitive (i.e., firms are price takers and adjust nominal prices in each period). The production function for final goods output $(\mathrm{Y})$ takes intermediate goods (distributed over $(0,1)$ ) as inputs $\left(\mathrm{Y}_{\mathrm{j}}\right)$ :

$$
\mathrm{Y}=\left[\int_{0}^{1} \mathrm{Y}_{\mathrm{i}}^{\theta} \mathrm{di}\right]^{1 / \theta} \text {. }
$$

Cost minimization by final goods firms yields the demand functions for intermediate goods

$$
\mathrm{Y}_{\mathrm{i}}=\mathrm{Y}\left(\mathrm{X}_{\mathrm{i}} / \mathrm{P}\right)^{-1 /(1-\theta)}
$$

where $X_{i}$ is the price of good $i$, and $P$ is the aggregate price index $\left(=\left[\int_{0}^{1} X_{i}^{\theta /(\theta-1)} d i\right]^{(\theta-1) / \theta}\right)$.

\section{Intermediate Goods}

Intermediate goods firms set nominal prices according to the staggered price setting model as above, and meet demand (from the previous subsection) at the posted price. Firms produce output according to the production function

$$
\mathrm{Y}_{\mathrm{it}}=\left(\mathrm{K}_{\mathrm{it}}{ }^{\mathrm{a}} \mathrm{N}_{\mathrm{it}}{ }^{1-\mathrm{a}}\right)^{\gamma} \text {, }
$$


where $\gamma>1$ represents returns to scale. Returns to scale are greater than one because monopolistic competition among intermediate goods producers results in prices greater than marginal cost, so that zero profits in the steady state require increasing returns to scale. Minimizing wage and rental costs then yields the equilibrium conditions

$$
\begin{aligned}
& \mathrm{W}_{\mathrm{t}}=(1-\mathrm{a}) \gamma \mathrm{MC}_{\mathrm{it}} \mathrm{Y}_{\mathrm{it}} / \mathrm{N}_{\mathrm{it}}, \\
& \mathrm{U}_{\mathrm{t}}=\mathrm{a} \gamma \mathrm{MC}_{\mathrm{it}} \mathrm{Y}_{\mathrm{it}} / \mathrm{K}_{\mathrm{it}},
\end{aligned}
$$

where real marginal cost MC (or the inverse of the price-marginal cost markup) is the lagrange multiplier on (3.5) in the minimization. In steady state, zero profits imply $\gamma=1 / \mathrm{MC}=1 / \theta$ (the markup from the CES demand function above).

Equations (3.5)-(3.7) contain firm specific variables. Below, a log-linear approximation to the equilibrium conditions will be used to solve for aggregate dynamics. Integrating (3.5)-(3.7) over the unit interval containing intermediate goods producers and log-linearizing yields equations that, to a first order log-linear approximation, are identical to (3.5)-(3.7) with the individual firm subscripts (i) removed. ${ }^{7}$ Aggregation in sections 4 and 5 below uses the same approximation.

\section{Money}

The treatment of monetary policy deviates importantly from that in the previous section and the majority of the literature by using a nominal interest rate rule to specify monetary policy. Specifying monetary policy in terms of a nominal interest rate reaction function has two advantages. First, monetary policymakers clearly view nominal interest rates as their policy instrument, and most of the VAR literature examining shocks to monetary policy focuses on innovations to nominal interest rates. This makes the focus on an interest rate rule herein a more appropriate description of actual policy behavior. The second advantage comes from not having to specify a money demand function. In particular, a money demand function, derived say from money in the utility function as in Chari, Kehoe, and McGrattan (1996), serves only to determine the behavior of real balances and the nominal money supply in response to a policy shock when the monetary authority follows a nominal interest rate rule (and real balances enter the utility function separably). The irrelevance of the money demand function for the output and price dynamics arises because, under separability, real balances only enter the money demand function; the other equilibrium conditions discussed above do not make any reference to money. This irrelevance of the money demand function under nominal interest rate rules is good news given the empirical instability experienced by money demand models, and suggests that the sensitivity of previous results on staggered price setting (such as Chari, Kehoe, and McGrattan 
(1996)) to parameters of the money demand function (see Dotsey, King and Wolman (1997) and Erceg (1997)) are not central for the impact of staggered price setting on models in which policy is governed by nominal interest rate rules. ${ }^{8}$

The equations governing the nominal interest rate ( $\mathbf{l}$ ) are

$$
\begin{aligned}
& \mathrm{r}_{\mathrm{t}+1}=\phi_{\mathrm{y}} \mathrm{y}_{\mathrm{t}}+\phi_{\Delta \mathrm{p}} \Delta \mathrm{p}_{\mathrm{t}}+\mathrm{v}_{\mathrm{t}} \\
& \mathrm{v}_{\mathrm{t}}=\rho \mathrm{v}_{\mathrm{t}-1}+\mathrm{e}_{\mathrm{t}}, \mathrm{e}_{\mathrm{t}} \text { i.i.d. } \\
& \mathrm{r}_{\mathrm{t}+1}=\mathrm{v}_{\mathrm{t}+1}-\mathrm{E}_{\mathrm{t}} \Delta \mathrm{p}_{\mathrm{t}+1}
\end{aligned}
$$

The first equation is a simple reaction function relating the nominal interest rate to inflation and output (similar reaction functions are found in Taylor (1993) and Woodford (1996)). The exogenous shock to policy, $\mathrm{v}$, is autocorrelated to capture the persistence of shifts in policy. Note that under this specification the nominal interest rate at $\mathrm{t}+1$ is known at time $\mathrm{t}\left(\mathrm{t}_{\mathrm{t}+1}\right.$ is in the time $\mathrm{t}$ information set). The third equation is simply the Fisher equation relating real and nominal interest rates.

\section{Solution}

The solution to the above model is found by log-linearizing the equilibrium conditions and solving for the unique rational expectations solution to the linearized system of equations. This solution can be written as

$$
\mathrm{z}_{\mathrm{t}+1}=\mathrm{Az}_{\mathrm{t}}+\mathrm{Be}_{\mathrm{t}}
$$

where $\mathrm{A}$ and $\mathrm{B}$ are determined by the parameters of the model, and $\mathrm{z}$ is the vector of variables in the model. ${ }^{9}$

In the exploration of the model which follows, the period under investigation will be a half year (to correspond with the simple two period price setting of the static model). The parameters are chosen such that the annual real interest rate is $4 \%$, the annual depreciation rate is $10 \%$, labor's share of output in the steady state is $0.7(a=0.3)$, and the elasticity of labor supply is infinite ( $\mathrm{s}=0)$. These values are close to standard in the equilibrium business cycle literature, and, in conjunction with a choice for returns to scale, pin down the steady state. While $s=0$ is low given microeconomic values of the labor supply elasticity, such values are necessary in a typical real business cycle investigation to generate realistic employment volatility.

The parameters of the nominal interest rate rule are set at the values suggested in Taylor (1993); $\phi_{\mathrm{y}}=0.5$ and $\phi_{\Delta \mathrm{p}}=1.5$. Over the 1987-1996 period, the residuals from this interest rate rule follow an AR1 with autoregressive coefficient equal to 0.6 (at a quarterly frequency); this result leads to $\rho$ equal to 0.5 in the impulse responses considered below, which may be a little high given the 
half-year periodicity in the base model, but is at least illustrative of how the model works.

Examples illustrating the staggered price setting model are contained in figures 1-3, which contain impulse responses for output and marginal cost to a unit decrease in the nominal interest rate for various values of increasing returns to scale. ${ }^{10}$ In figure $1, \gamma=1.01$; this nearly constant returns to scale is consistent with the overwhelming fraction of the literature on sticky prices in DGE models. The staggered price setting model in figure 1 results in no endogenous price stickiness; by the period after the shock (when all firms have adjusted), output is below trend, illustrating the oscillatory dynamics implied by the base staggered price setting model under typical parameterizations. The key to this result is the sharp increase in marginal cost in the impulse response, which results in strong incentives for price adjustment.

Figure 2 increases $\gamma$ to 1.35. Again, the staggered price model yields effectively no endogenous price rigidity, with output below trend in the period following the shock. The lack of endogenous persistence is unsurprising for these parameters; remember that in the optimizing IS/LM model staggered prices yielded little persistence unless the elasticity of marginal cost with respect to output (b in section 2) was quite close to zero, and the dynamic model shares this property. Even with $\gamma=1.35$ (an empirically implausible value), marginal cost responds too strongly to a shock to nominal interest rates to generate persistent output responses. Figure 3 considers $\gamma=1.75$. The staggered price model in figure 3 generates a persistent response, with a smooth return of output to the steady state following an expansionary shock to the nominal interest rate. The persistence under staggering occurs because marginal cost is flat (in fact, marginal cost falls), as indicated in the impulse response function, and hence firms have little desire to adjust prices. In effect, the dampening influence on output of rising costs has been greatly reduced by the increasing returns. This intuition is suspiciously familiar from the static model in section 2, where flat marginal cost was key for persistence. Note also that this large degree of increasing returns would generate indeterminacy (i.e., stationary sunspot equilibria) under price flexibility, again because the fairly large degree of increasing returns eliminates the dampening effect of rising costs on self-fulfilling expectations (see Benhabib and Farmer (1994)). It is this lessening of fluctuation dampening that links features conducive to sunspot fluctuations and features conducive to price rigidity.

These results reveal that staggered price setting does not result in persistent output responses to monetary shocks for DGE economies parameterized to lie near real business cycle models, as has been typical in the literature on sticky prices in one sector DGE models (Chari, Kehoe and McGrattan (1996) and, with additional complications, Dotsey, King and Wolman (1996)). ${ }^{11}$ Staggered price 
setting generates endogenous price rigidity and persistent output responses when the parameters values imply low curvature in marginal cost, a feature that is conducive to sunspot fluctuations in flexible price models.

\section{A Two Sector Dynamic General Equilibrium Economy}

The one sector DGE model of the previous section generates persistent output responses through price stickiness under staggered price setting when parameterized in the region with low curvature in marginal cost. While the intuition follows directly from the optimizing IS/LM model and relies on flat marginal cost, the relevance of the result on endogenous stickiness may be questioned given that the required degree of returns to scale (@1.7) is far outside recent estimates of return to scale (Basu and Fernald (1994)). This section discusses persistence under staggered price setting in a two sector model, where the work of Benhabib and Farmer (1996) suggests far lower increasing returns generate a model with low curvature (and hence less output dampening and the possibility of sunspot fluctuations).

\section{Consumers}

Consumers have the same preferences as before. Consumers' budget constraint and capital accumulation equations are given by

$$
\begin{aligned}
& \mathrm{C}_{\mathrm{t}}+\mathrm{P}_{\mathrm{t}}^{\mathrm{I}} \mathrm{I}_{\mathrm{t}}+\mathrm{B}_{\mathrm{t}+1}=\mathrm{W}_{\mathrm{t}} \mathrm{N}_{\mathrm{t}}+\mathrm{U}_{\mathrm{t}} \mathrm{K}_{\mathrm{t}}+\Pi_{\mathrm{t}}+\left(1+\mathrm{r}_{\mathrm{t}}\right) \mathrm{B}_{\mathrm{t}}, \\
& \mathrm{K}_{\mathrm{t}+1}=\mathrm{I}_{\mathrm{t}}+(1-\mathrm{d}) \mathrm{K}_{\mathrm{t}},
\end{aligned}
$$

where $\mathrm{P}^{\mathrm{I}}$ is the price (in terms of the final consumption good) of the investment good (which differs from one because the goods are produced in different sectors), and the other variables remain the same as in the previous section. Utility maximization implies the familiar equilibrium conditions:

$$
\begin{aligned}
& \mathrm{P}_{\mathrm{t}}^{\mathrm{I}} / \mathrm{C}_{\mathrm{t}}=\beta \mathrm{E}_{\mathrm{t}}\left\{1 / \mathrm{C}_{\mathrm{t}+1}\left[\mathrm{U}_{\mathrm{t}+1}+(1-\mathrm{d}) \mathrm{P}_{\mathrm{t}+1}^{\mathrm{I}}\right]\right\}=\beta \mathrm{E}_{\mathrm{t}}\left\{1 / \mathrm{C}_{\mathrm{t}+1}\left[1+\mathrm{r}_{\mathrm{t}+1}\right]\right\}, \\
& \mathrm{C}_{\mathrm{t}} \mathrm{N}_{\mathrm{t}}^{\mathrm{s}}=\mathrm{W}_{\mathrm{t}} .
\end{aligned}
$$

Equilibrium requires that output equals consumption plus investment

$$
\mathrm{Y}_{\mathrm{t}}=\mathrm{C}_{\mathrm{t}}+\mathrm{P}_{\mathrm{t}}^{\mathrm{I}} \mathrm{I}_{\mathrm{t}} \text {, }
$$

where output is denominated in consumption units (so the real price of consumption in one).

\section{Final Goods}

The final consumption and investment good sectors are competitive (i.e., firms are price takers and adjust nominal prices in each period). The production function for final goods $\mathrm{C}$ and $\mathrm{I}$ take sector 
specific intermediate goods $\left(\mathrm{C}_{\mathrm{i}}\right.$ and $\left.\mathrm{I}_{\mathrm{i}}\right)$ (distributed over $\left.(0,1)\right)$ as inputs:

$$
\begin{aligned}
& \mathrm{C}=\left[\int_{0}^{1} \mathrm{C}_{\mathrm{i}}{ }_{\mathrm{i}} \mathrm{di}\right]^{1 / \theta}, \\
& \mathrm{I}=\left[\int_{0}{ }^{1} \mathrm{I}_{\mathrm{i}}{ }^{\theta} \mathrm{di}\right]^{1 / \theta} .
\end{aligned}
$$

Cost minimization by final good firms yields the demand functions for intermediate goods

$$
\begin{aligned}
& C_{\mathrm{i}}=\mathrm{C}\left(\mathrm{X}_{\mathrm{C}} / \mathrm{Q}_{\mathrm{C}}\right)^{-1 /(1-\theta),} \\
& \mathrm{I}_{\mathrm{i}}=\mathrm{Y}\left(\mathrm{X}_{\mathrm{II}} / \mathrm{Q}_{\mathrm{I}}\right)^{-1 /(1-\theta)},
\end{aligned}
$$

where $\mathrm{X}_{\mathrm{Gi}}$ is the nominal price of good $\mathrm{i}$ in sector $\mathrm{G}$, and $\mathrm{Q}_{\mathrm{G}}$ is the nominal aggregate price index for sector $\mathrm{G}\left(=\left[\int_{0}^{1} \mathrm{X}_{\mathrm{Gi}}{ }^{\theta /(\theta-1)} \mathrm{di}\right]^{(\theta-1) / \theta}\right)$.

\section{Intermediate Goods}

Intermediate consumption and investment good firms will set nominal prices according staggered price setting, discussed below, and meet demand (from the previous subsection) at the posted price. Consumption and investment good firms produce output according to the production function

$$
\begin{aligned}
& \mathrm{C}_{\mathrm{it}}=\left(\mathrm{K}_{\mathrm{Cit}}{ }^{\mathrm{a}} \mathrm{N}_{\mathrm{Cit}}{ }^{1-\mathrm{a}}\right)^{\gamma}, \\
& \mathrm{I}_{\mathrm{it}}=\left(\mathrm{K}_{\mathrm{Iit}}{ }^{a} \mathrm{~N}_{\mathrm{Iit}}{ }^{1-\mathrm{a}}\right)^{\gamma},
\end{aligned}
$$

where $\gamma>1$ represents returns to scale. Returns to scale are again greater than one because monopolistic competition among intermediate goods producers results in prices greater than marginal cost, so that zero profits in the steady state require increasing returns. Note that (4.5), with $\gamma \neq 1$, implies a two sector economy. Minimizing wage and rental costs yields the equilibrium conditions

$$
\begin{aligned}
& \mathrm{W}_{\mathrm{t}}=(1-\mathrm{a}) \gamma \mathrm{MC}_{\mathrm{Git}} \mathrm{G}_{\mathrm{it}} / \mathrm{N}_{\text {Git }}, \\
& \mathrm{U}_{\mathrm{t}}=\mathrm{a} \gamma \mathrm{MC}_{\mathrm{Git}} \mathrm{G}_{\mathrm{it}} / \mathrm{K}_{\text {Git }},
\end{aligned}
$$

for $\mathrm{G}=\mathrm{C}$ or I. Real (consumption based) marginal cost $\mathrm{MC}_{\mathrm{G}}$ is the lagrange multiplier on (4.5) in the cost minimization problem. For the consumption sector, $\mathrm{MC}$ is the inverse of the price-marginal cost markup, but in the investment sector MC is the inverse of the price-marginal cost markup times the price of investment in terms of consumption, since nominal marginal cost in the investment sector is scaled by the aggregate nominal price of consumption to yield consumption based MC. In the steady state, zero profits imply $\gamma=1 / \mathrm{MC}^{\mathrm{C}}=\mathrm{P}^{\mathrm{I}} / \mathrm{MC}^{\mathrm{I}}=1 / \theta$ (the markup from the CES demand functions in each sector). Also note that factors are perfectly mobile across sectors, implying that both sectors face the same consumption based factor prices in (4.6) and (4.7).

Price setting follows staggering as in section 2. For each sector, the log-linearized price adjustment block is given by

$$
\mathrm{x}_{\mathrm{Gt}}=1 / 2 \mathrm{E}_{\mathrm{t}}\left[\mathrm{q}_{\mathrm{Ct}}+\mathrm{mc}_{\mathrm{Gt}}+\mathrm{q}_{\mathrm{Ct}+1}+\mathrm{mc}_{\mathrm{Gt}+1}\right],
$$




$$
\mathrm{q}_{\mathrm{Gt}}=1 / 2\left(\mathrm{x}_{\mathrm{Gt}}+\mathrm{x}_{\mathrm{Gt}-1}\right),
$$

for $\mathrm{G}=\mathrm{C}$ and $\mathrm{I}$. These equations are simply (2.8)-(2.9) for each sector. Note that the nominal prices chosen by price setters in both sectors $(\mathrm{x})$ scale marginal cost by the nominal consumption price $\left(\mathrm{q}^{\mathrm{C}}\right)$ because real marginal costs are denoted in consumption units.

\section{Aggregation}

Feasibility requires that the labor and capital inputs used in each sector sum to the economywide totals

$$
\begin{aligned}
& \mathrm{K}=\int_{0}{ }^{1} \mathrm{~K}_{\mathrm{Ii}} \mathrm{di}+\int_{0}{ }^{1} \mathrm{~K}_{\mathrm{Ci}} \mathrm{di}, \\
& \mathrm{N}=\int_{0}{ }^{1} \mathrm{~N}_{\mathrm{Ii}} \mathrm{di}+\int_{0}{ }_{0} \mathrm{~N}_{\mathrm{Ci}} \mathrm{di} .
\end{aligned}
$$

\section{Money}

The nominal interest rate rule is the same as in the previous section.

\section{Solution}

The solution to the two sector model is found by log-linearizing the equilibrium conditions and solving for the unique rational expectations solution to the linearized system of equations. The parameters (other than returns to scale) remain the same as in the previous section.

Impulse responses to a unit decrease in the nominal interest rate for $\gamma=1.01,1.12$ and 1.2 are contained in figures 4-6 for output, marginal cost in the consumption sector, and marginal cost in the investment sector. The staggered price setting model in figure 4 for $\gamma=1.01$ yields the familiar results for parameterizations with strongly procyclical marginal cost; in the period following the shock (when all firms have adjusted), output is below trend. The key to the result is again the sharp increase in marginal cost (in both sectors) in the impulse response, which results in strong incentives for price adjustment. Figures 5 and 6 increase $\gamma$ to 1.12 and 1.2, respectively. The staggered price model in figures 5 and 6 generate persistence for these lower values of returns to scale! In fact, figure 6 generates extremely strong persistence. This occurs because marginal cost in the investment sector actually falls after a monetary shock, as indicated in the impulse response functions, and hence firms in the cyclical sector have little desire to adjust prices. This intuition is growing familiar from the static model and one sector model in sections 2 and 3, where flat marginal cost was key for persistence.

What is the intuition for acyclical marginal cost in the two sector model with relatively small 
degrees of increasing returns? In response to a fall in the nominal interest rate, labor and capital shift from the consumption sector to the interest-sensitive investment sector. This transfer of resources leads to the fall in marginal cost in the investment sector, as a small degree of increasing returns in the investment sector combined with the transfer of inputs across sectors results in lower marginal cost. This same intuition suggests that including a home production sector, as in Perli (1996), is an alternative to the consumption and investment sector formulation of this section, as then home production acts as the sector that sheds labor input during the boom.

In summary, this section has demonstrated that for relative small, and perhaps plausible, increasing returns, a two sector dynamic general equilibrium economy with staggered price setting generates endogenous price rigidity and persistent output responses to monetary shocks. As in section 2 and 3, flat marginal cost in the procyclical sector is the key, because flat marginal cost yields little dampening of output fluctuations. In addition, Benhabib and Farmer (1996) and Perli (1996) demonstrate that two sector models like that of this section generate sunspot fluctuations under price flexibility for increasing returns in the range considered in the sticky price versions above, again illustrating that features that lower the dampening effect of rising costs in sticky price models also lower the tendency of rising costs to dampen sunspot fluctuations under price flexibility.

\section{A Model with Countercylical Markups}

So far, both models capable of generating substantial persistence under staggered price setting rely on extremely flat marginal cost, generated through increasing returns. This emphasis on flat marginal cost focuses on one strand of "real rigidities" emphasized in the new-Keynesian literature. The other strand of "real rigidity" emphasized particularly in Ball and Romer (1990) and Kimball (1995) focuses on the sluggishness induced in nominal price adjustment when relative price considerations become more important during economic booms because "competition" rises. Several models formalize the notion of increased competition during booms. Rotemberg and Woodford (1995) present a model in which collusive behavior is more difficult to maintain during expansions. Gali (1994) presents a model in which the elasticity of demand for procyclical durable goods is higher than the elasticity of demand for nondurable goods, and hence the more "competitive" sector plays a larger role in price determination during booms. Finally, Ball and Romer (1990) and especially Kimball (1995) present models in which the demand curve is "kinked" and has a higher elasticity when demand is high. The implication of increased competition in expansions arising in each of these models is that desired price markups are countercyclical. This section develops a sticky price version of Gali (1994), 
showing that countercyclical markups generate a great deal of persistence under staggered price setting for certain parameter values. Consistent with the models of the previous two sections, the countercyclical markup model of Gali (1994) used below to generate price rigidity was designed to show the possibility of sunspot fluctuations arising in a flexible-price, constant returns to scale economy. ${ }^{12}$

\section{Consumers}

Consumers' preferences remain the same as in the one sector model. Their budget constraint and capital accumulation equations are given by

$$
\begin{aligned}
& \mathrm{C}_{\mathrm{t}}+\mathrm{I}_{\mathrm{t}}+\mathrm{B}_{\mathrm{t}+1}=\mathrm{W}_{\mathrm{t}} \mathrm{N}_{\mathrm{t}}+\mathrm{U}_{\mathrm{t}} \mathrm{K}_{\mathrm{t}}+\Pi_{\mathrm{t}}+\left(1+\mathrm{r}_{\mathrm{t}}\right) \mathrm{B}_{\mathrm{t}}, \\
& \mathrm{K}_{\mathrm{t}+1}=\mathrm{I}_{\mathrm{t}}+(1-\mathrm{d}) \mathrm{K}_{\mathrm{t}} .
\end{aligned}
$$

Utility maximization implies the familiar equilibrium conditions:

$$
\begin{aligned}
& 1 / \mathrm{C}_{\mathrm{t}}=\beta \mathrm{E}_{\mathrm{t}}\left\{1 / \mathrm{C}_{\mathrm{t}+1}\left[\mathrm{U}_{\mathrm{t}+1}+(1-\mathrm{d})\right]\right\}=\beta \mathrm{E}_{\mathrm{t}}\left\{1 / \mathrm{C}_{\mathrm{t}+1}\left[1+\mathrm{r}_{\mathrm{t}+1}\right]\right\}, \\
& \mathrm{C}_{\mathrm{t}} \mathrm{N}_{\mathrm{t}}^{\mathrm{s}}=\mathrm{W}_{\mathrm{t}} .
\end{aligned}
$$

Equilibrium requires that output equals consumption plus investment

$$
\mathrm{Y}_{\mathrm{t}}=\mathrm{C}_{\mathrm{t}}+\mathrm{I}_{\mathrm{t}} \text {. }
$$

\section{Final Goods}

The modification in this model from the one sector model in section 3 comes in the final consumption and investment goods sectors. The production function for final goods $\mathrm{C}$ and $\mathrm{I}$ both take the same intermediate goods $\mathrm{Y}$ (distributed over $(0,1))$ as inputs:

$$
\begin{aligned}
& \mathrm{C}=\left[\int_{0}^{1} \mathrm{Y}_{\mathrm{Ci}}{ }^{\theta} \mathrm{di}\right]^{1 / \theta}, \\
& \mathrm{I}=\left[\int_{0}^{1} \mathrm{Y}_{\mathrm{Ii}}{ }^{\xi} \mathrm{di}\right]^{1 / \xi},
\end{aligned}
$$

where $Y_{G i}$ represents the amount of intermediate good i used in sector $\mathrm{G}\left(=\mathrm{C}\right.$ or I). ${ }^{13}$ Cost minimization by final goods firms yields the demand functions for intermediate goods (summed over the demand of both the investment and consumption final goods sectors)

$$
Y_{i}=C\left(X_{i} / P\right)^{-1 /(1-\theta)}+I\left(X_{i} / P\right)^{-1 /(1-\xi)},
$$

where $\mathrm{X}_{\mathrm{i}}$ is the nominal price of good $\mathrm{i}$, and $\mathrm{P}$ is the nominal aggregate price index. Note that the demand of final consumption goods firms has a different elasticity from that of investment goods firms.

\section{Intermediate Goods}


Intermediate firms will set nominal prices according to staggered price setting, discussed below, and again meet demand (from the previous subsection) at the posted price. The production function of intermediate goods firms is

$$
\mathrm{Y}_{\mathrm{it}}=\mathrm{K}_{\mathrm{it}}{ }^{\mathrm{a}} \mathrm{N}_{\mathrm{it}}{ }^{1-\mathrm{a}}-\mathrm{F} \text {, }
$$

where $\mathrm{F}$ is a fixed cost generating increasing returns to scale. Returns to scale are again greater than one because monopolistic competition among intermediate goods producers results in prices greater than marginal cost, so that zero profits in the steady state require increasing returns to scale. However, (5.5) does not assume declining marginal costs, as the increasing returns are generated through a fixed cost. $^{14}$ Minimizing wage and rental costs yields the equilibrium conditions

$$
\begin{aligned}
& \mathrm{W}_{\mathrm{t}}=(1-\mathrm{a}) \gamma \mathrm{MC}_{\mathrm{it}}\left(\mathrm{K}_{\mathrm{it}} / \mathrm{N}_{\mathrm{it}}\right)^{\mathrm{a}} \\
& \mathrm{U}_{\mathrm{t}}=\mathrm{a} \gamma \mathrm{MC}_{\mathrm{it}}\left(\mathrm{K}_{\mathrm{it}} / \mathrm{N}_{\mathrm{it}}\right)^{\mathrm{a}-1} .
\end{aligned}
$$

Price setting follows a two period staggered pattern, so the minimization problem for the price setting firm is similar to that in section 2. Price discrimination by intermediate good firms between consumption and investment good demand is not permitted, so both consumption and investment final good producers face the same prices. Substituting the demand function for intermediate goods derived above and solving the first order condition yields

$\mathrm{X}_{\mathrm{it}}=\left[\sum_{\mathrm{j}=0}{ }^{1} \mathrm{E}_{\mathrm{t}}\left\{\beta^{\mathrm{j}} \Lambda_{\mathrm{t}+\mathrm{j}} \mathrm{MC}_{\mathrm{it+j}} \mathrm{P}_{\mathrm{t}+\mathrm{j}}\left(\mathrm{C}_{\mathrm{it}+\mathrm{j}}+(1-\theta) /(1-\xi) \mathrm{I}_{\mathrm{it}+\mathrm{j}}\right)\right\}\right] / \theta\left[\sum_{\mathrm{j}=0}{ }^{1} \mathrm{E}_{\mathrm{t}}\left\{\beta^{\mathrm{j}} \Lambda_{\mathrm{t}+\mathrm{j}}\left(\theta \mathrm{C}_{\mathrm{it}+\mathrm{j}}+\xi(1-\theta) /(1-\xi) \mathrm{I}_{\mathrm{it}+\mathrm{j}}\right)\right\}\right]$.

This expression indicates that nominal prices are a markup over marginal cost over the period for which nominal prices are fixed, but the desired static (or flexible price) markup is no longer necessarily constant over time; in particular, the desired markup depends on the composition of demand. For example, if $\xi>\theta$, investment demand is more sensitive to relative prices than consumption demand, and the desired markup falls when investment is expected to be high. This specification naturally leads to countercyclical markups, since the investment share of expenditure rises during an expansion. Note that in the steady state of the model (with $\beta \approx 1$ ), the markup is

$$
\mathrm{X}_{\mathrm{i}} / \mathrm{PMC}_{\mathrm{i}}=\mu=[(\mathrm{C}+(1-\theta) /(1-\xi) \mathrm{I}] / \theta[\theta \mathrm{C}+\xi(1-\theta) /(1-\xi) \mathrm{I}] .
$$

lustrating how the "average markup" depends on the shares of consumption and investment in aggregate output.

\section{Money}

The nominal interest rate rule is the same as in the previous section.

\section{Solution}


The solution to the countercyclical markup model is found by log-linearizing the equilibrium conditions and solving for the unique rational expectations solution to the linearized system of equations. Most parameter values remain unchanged from previous sections. The fixed cost $\mathrm{F}$ is chosen such that returns to scale are 1.4, and the average markup $(\mu)$ is also set at 1.4 (so profits are zero in the steady state).

Impulse responses to a unit decrease in the nominal interest rate for $1 / \xi=1.40,1.20$ and 1.09 are contained in figures 7-9 for output and marginal cost. When $1 / \xi=1.40$, the desired markups for both the consumption and investment goods' demand functions are identical $(1 / \theta=1 / \xi=1.40)$, and hence the desired markup does not fluctuate with output movements. Therefore, figure 7 looks like the standard impulse response in a one sector model with strongly procyclical marginal cost, with output below trend in the second period after all prices adjust. These oscillatory dynamics are dampened somewhat in figure 8 , because here the desired markup is somewhat countercyclical, and hence the increase in marginal cost does not lead to as rapid price adjustment. The countercyclical desired markup arises because the desired markup for investment goods demand is $1 / \xi=1.20$, whereas the desired markup for consumption goods demand is $1 / \theta=1.55$, so that the increase in investment relative to consumption following a fall in the nominal interest rate raises "competitiveness". Figure 9 illustrates that this effect substantially increases persistence when the degree of competitiveness embedded in investment goods demand is much higher than that in consumption goods demand $(1 / \xi=$ $1.09,1 / \theta=7.60)$.

This section has therefore illustrated that a dynamic general equilibrium economy with countercyclical markups can generate endogenous price rigidity and persistent output responses to monetary policy shocks under staggered price setting. As in every model in this paper, a "flat" model structure, i.e. one that prevents substantial output dampening arising from rising marginal costs, is the key. Countercyclical desired markups deliver "flatness" by making the fall in markups that accompanies output expansions when prices are rigid consistent with firms' wishes. This type of "flatness" is also key to the models using countercyclical markups to generate output fluctuations due to sunspot shocks under price flexibility, such as Gali (1994), Rotemberg and Woodford (1995), and Schmitt-Grohe (1997).

\section{Discussion}

Analysis of several DGE models reveals that endogenous price stickiness (and therefore persistent output responses to monetary shocks) only arises when model features that enhance "real 
rigidity" are incorporated; this result is unsurprising, as it simply corresponds to Ball and Romer's (1990) static emphasis on real rigidities as key to price rigidity. The key to practical implementation of this insight is the illustration that real rigidities also tend to lead to indeterminacy or sunspot fluctuations under price flexibility. The intuitive link between features conducive to price rigidity and features conducive to sunspot fluctuations under price flexibility is that both types of models require that output fluctuations not be strongly damped by rising costs. This suggests that researchers interested in either sticky price or sunspot models should draw from each other's work, as this paper on price rigidity draws on the sunspot models of Benhabib and Farmer (1994,1996) and Gali (1994).

Future researchers may wish to incorporate "real rigidities" other than increasing returns or countercyclical markups in order to enhance endogenous price rigidity. The link between real rigidities and features conducive to sunspot fluctuations is particularly helpful in this regard. For example, Wen (1996) illustrates that variable capital utilization, combined with small increasing returns, can generate sunspot fluctuations. The ability of variable capital utilization to lower the elasticity of marginal cost with respect to output and enhance price rigidity is already being explored in Dotsey, King, and Wolman (1997). Another possibility is financial market imperfections which make the cost of capital less procyclical (perhaps because net worth increases and hence lowers agency costs in a boom). Kiley (1997a) illustrates that this mechanism for lowering the procyclicality of marginal costs can lead to sunspot fluctuations, and, following the intuition herein, financial market imperfections of this type also raise endogenous price rigidity under staggered price setting. 


\section{References}

Ball, L. and D. Romer. (1990) Real Rigidities and the Non-neutrality of Money. Review of Economic Studies 57:183-203.

Basu, S. and J. Fernald (1994) Constant Returns and Small Markups in U.S. Manufacturing. Federal

Reserve Board International Finance Division Discussion Paper 483.

Beaudry, P. and M. Devereux (1995) Money and the Real Exchange Rate with Sticky Prices and Increasing Returns. Carnegie Rochester Conference Series on Public Policy 43:55-102.

Benhabib, J. and R. Farmer (1994) Indeterminacy and Increasing Returns. Journal of Economic Theory 63:19-41.

Benhabib, J. and R. Farmer (1996) Indeterminacy and Sector Specific Externalities. Journal of Monetary Economics 37:421-443.

Benhabib, J. and R. Farmer (1997) Indeterminacy and Sunspots in Macroeconomics. Mimeo.

Binder, M. and Pesaran, M.H. (1995) Multivariate Rational Expectations Models and Macroeconometric Modelling: A Review and Some New Results. In M.H. Pesaran and M. Wickens, eds. Handbook of Applied Econometrics, Volume 1 (Blackwell Publishers, Cambridge).

Blanchard, O.J. and S. Fischer. (1989) Lectures on Macroeconomics (MIT Press, Cambridge).

Calvo, G.A. (1983) Staggered Prices in a Utility Maximizing Framework. Journal of Monetary Economics 12:383-398.

Chari, V.V., P.J. Kehoe, and E.R. McGrattan. (1996) Sticky Price Models of the Business Cycle: Can the Contract Multiplier Solve the Persistence Problem. NBER Working Paper 5809.

Cooper, R. and A. John (1988) Coordinating Coordination Failures in Keynesian Models. Quarterly Journal of Economics 103:441-463.

Diamond, P. (1982) Aggregate Demand Management in Search Equilibrium. Journal of Political Economy 90:881-894.

Dotsey, M., R.G. King, and A. Wolman (1996) State Dependent Pricing and the Dynamics of Business Cycles. Mimeo.

Dotsey, M., R.G. King, and A. Wolman (1997) Menu Costs, Staggered Price Setting and Elastic Factor Supply. Mimeo.

Erceg, C. (1997) Nominal Wage Rigidities and the Propagation of Aggregate Demand Disturbances. Mimeo.

Farmer, R. (1991) Sticky Prices. Economic Journal 101:1369-1379. 
Gali, J. (1994) Monopolistic Competition, Business Cycles, and the Composition of Aggregate Demand. Journal of Economic Theory 63:73-96.

Goodfriend, M. and R.G. King (1997) The New Neoclassical Synthesis and the Role of Monetary Policy. Mimeo.

Hairault, J.O. and F. Portier. (1993) Money, New Keynesian Macroeconomics and the Business Cycle. European Economic Review 37:1533-68.

Ireland, P.N. (1996) A Small, Structural, Quarterly Model for Monetary Policy Evaluation. Mimeo. Kiley, M.T. (1997a) Agency Costs and Capital Costs: Implications for Price Rigidity and Sunspot Fluctuations. Mimeo.

Kiley, M.T. (1997b) Partial Adjustment and Staggered Price Setting. Mimeo.

Kim, J. (1996) Monetary Policy in a Stochastic Equilibrium Model with Real and Nominal Rigidities. Mimeo.

Kimball, M. (1995) The Quantitative Analytics of the Basic Neomonetarist Model. Journal of Money, Credit, and Banking 27:1241-1277.

King, R.G. and M. Watson. (1996) Money, Output, Prices, and Interest Rates. Review of Economics and Statistics 78:35-53.

King, R.G. and A. Wolman. (1996) Inflation Targeting in a St. Louis Model of the 21st Century. NBER Working Paper 5507.

McCallum, B.T. and E. Nelson (1997) An Optimizing IS/LM Specification for Monetary Policy and Business Cycle Analysis. NBER Working Paper 5875.

Perli, R. (1996) Indeterminacy, Home Production, and the Business Cycle: A Calibrated Analysis. Mimeo.

Roberts, J. (1995) New-Keynesian Economics and the Phillips Curve. Journal of Money, Credit, and Banking 27:975-84.

Romer, D. (1996) Advanced Macroeconomics (McGraw Hill, New York).

Rotemberg, J.J. (1982) Monopolistic Price Adjustment and Aggregate Output. Review of Economic Studies. 49:517-531.

Rotemberg, J.J. (1987) The New Keynesian Microfoundations. NBER Macroeconomics Annual 1987. 69-104.

Rotemberg, J.J. (1996) Prices, Output, and Hours: An Empirical Analysis Based on a Sticky Price Model. Journal of Monetary Economics 37:505-533.

Rotemberg, J.J. and M. Woodford (1995) Dynamic General Equilibrium Models with Imperfectly 
Competitive Product Markets. In T.F. Cooley, ed. Frontiers of Business Cycle Research (Princeton University Press, Princeton) 243-293.

Rotemberg, J.J. and M. Woodford (1997) An Optimization Based Econometric Framework for the Evaluation of Monetary Policy. Mimeo.

Schmitt-Grohe, S. (1997) Comparing Four Models of Aggregate Fluctuations Due to Self-Fulfilling Expectations. Journal of Economic Theory 72:96-147.

Taylor, J.B. (1980) Aggregate Dynamics and Staggered Contracts. Journal of Political Economy 88:123.

Taylor, J.B. (1993) Discretion Versus Policy Rules in Practice. Carnegie Rochester Conference Series on Public Policy 39:195-214.

Uhlig, H. (1995) A Toolkit for Solving Nonlinear Dynamic Stochastic Models Easily. Federal Reserve Bank of Minneapolis Discussion Paper 101.

Wen, Y. (1997) Capacity Utilization Under Increasing Returns to Scale. Mimeo.

Woodford, M. (1996) Control of the Public Debt: A Requirement for Price Stability. NBER Working Paper 5684.

Yun, T. (1994) Nominal Price Rigidity, Money Supply Endogeneity, and Business Cycles. Journal of Monetary Economics 37:345-370. 
Figure 1: One Sector Staggered Price Model with $\gamma=1.01$

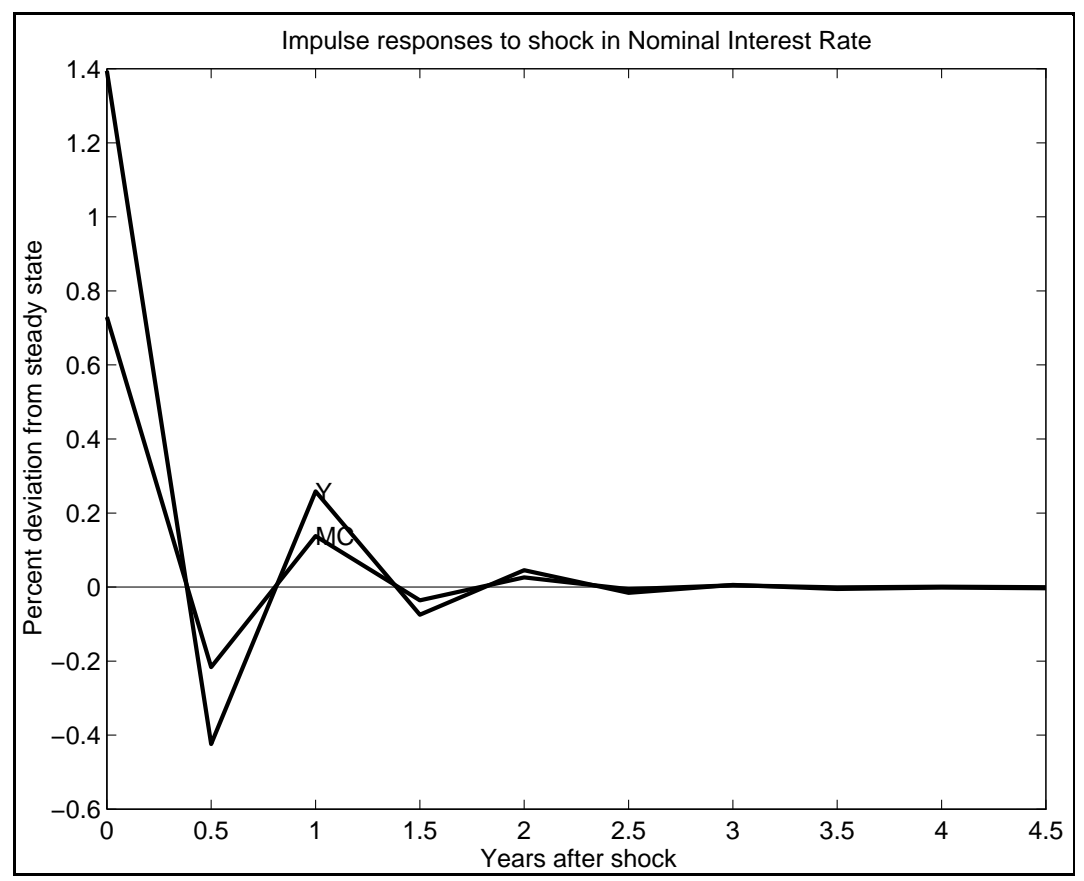

Figure 2: One Sector Staggered Price Model with $\gamma=1.35$

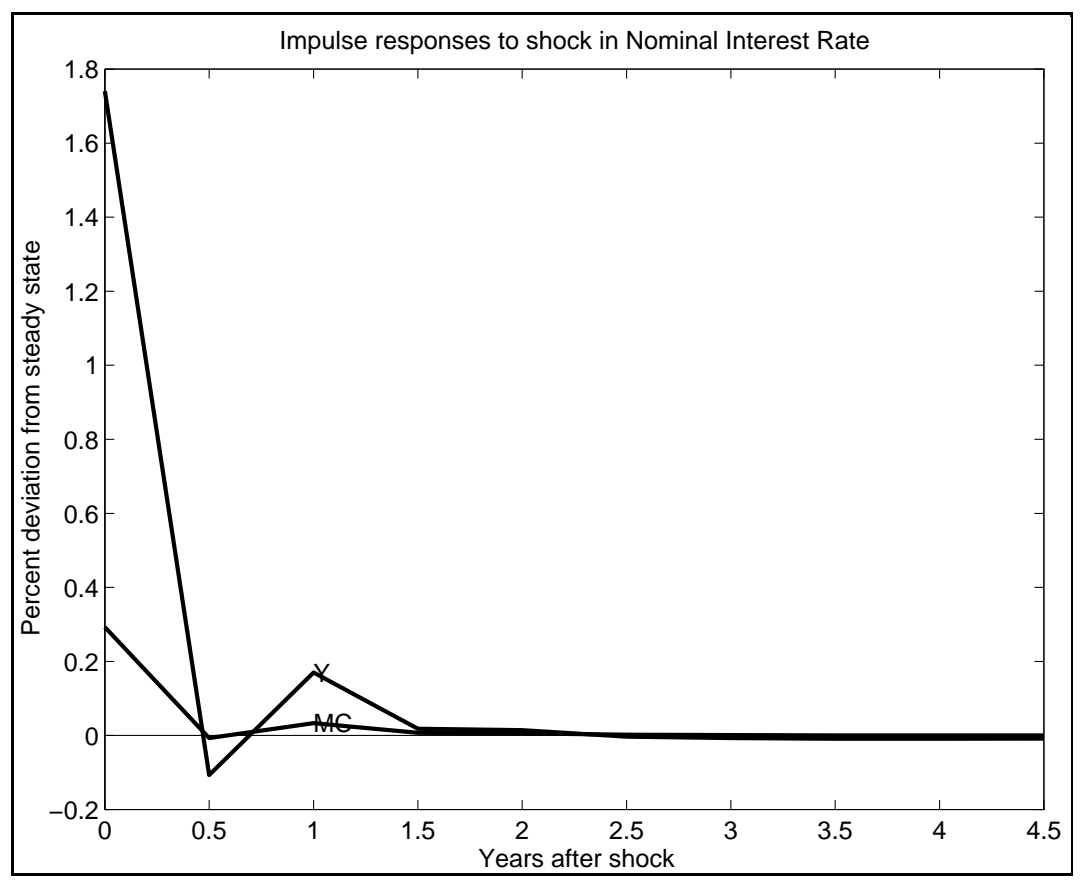


Figure 3: One Sector Staggered Price Model with $\gamma=1.75$

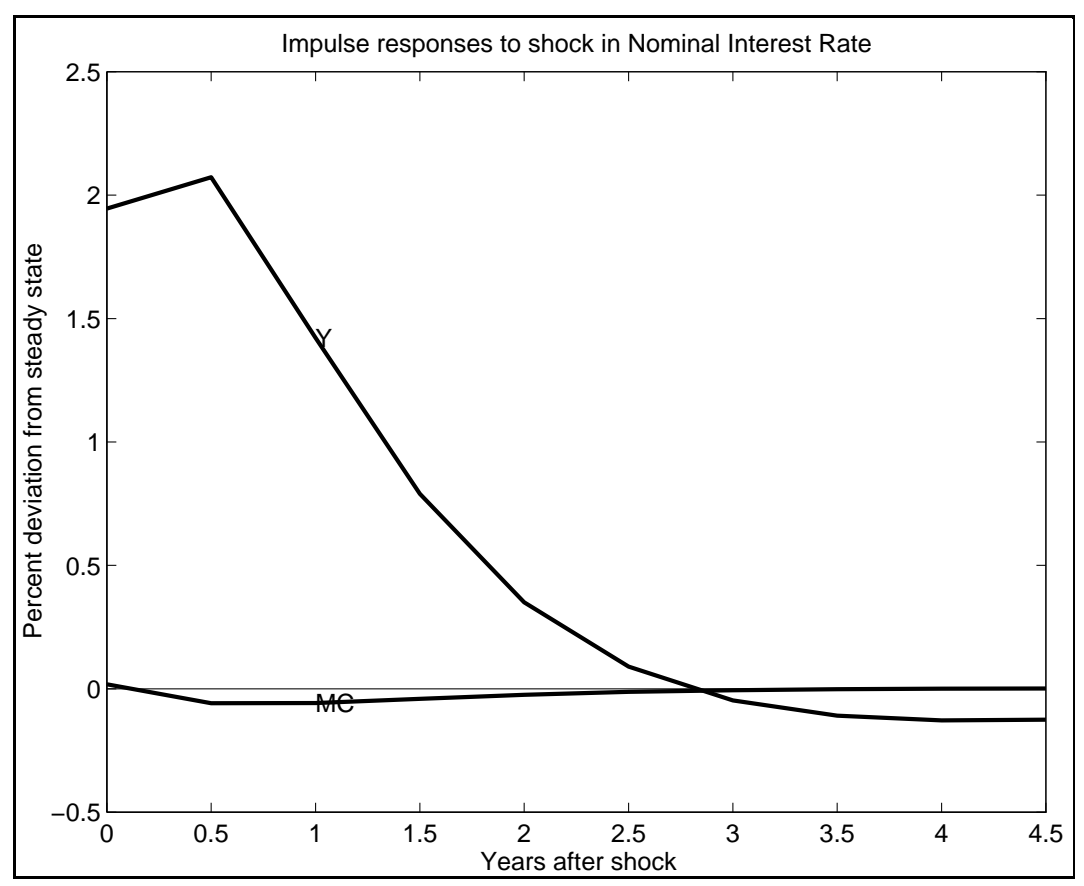

Figure 4: Two Sector Staggered Price Model with $\gamma=1.01$

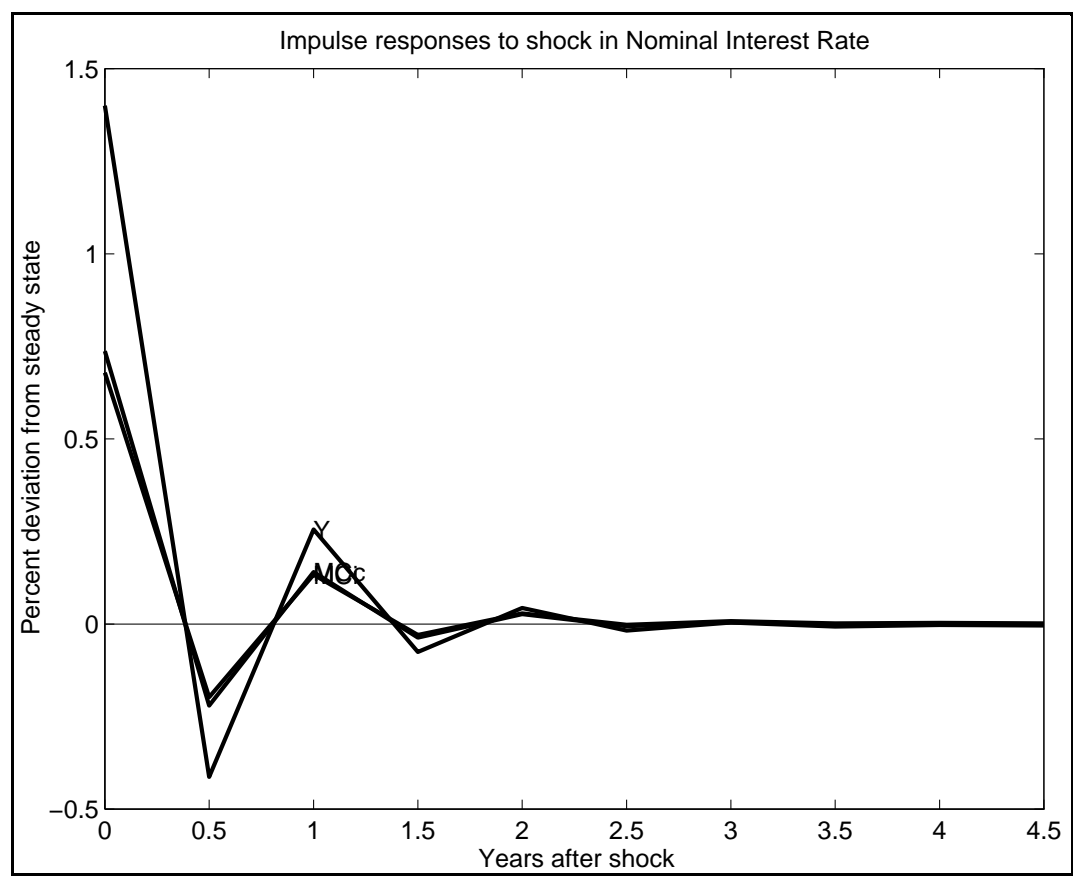


Figure 5: Two Sector Staggered Price Model with $\gamma=1.12$

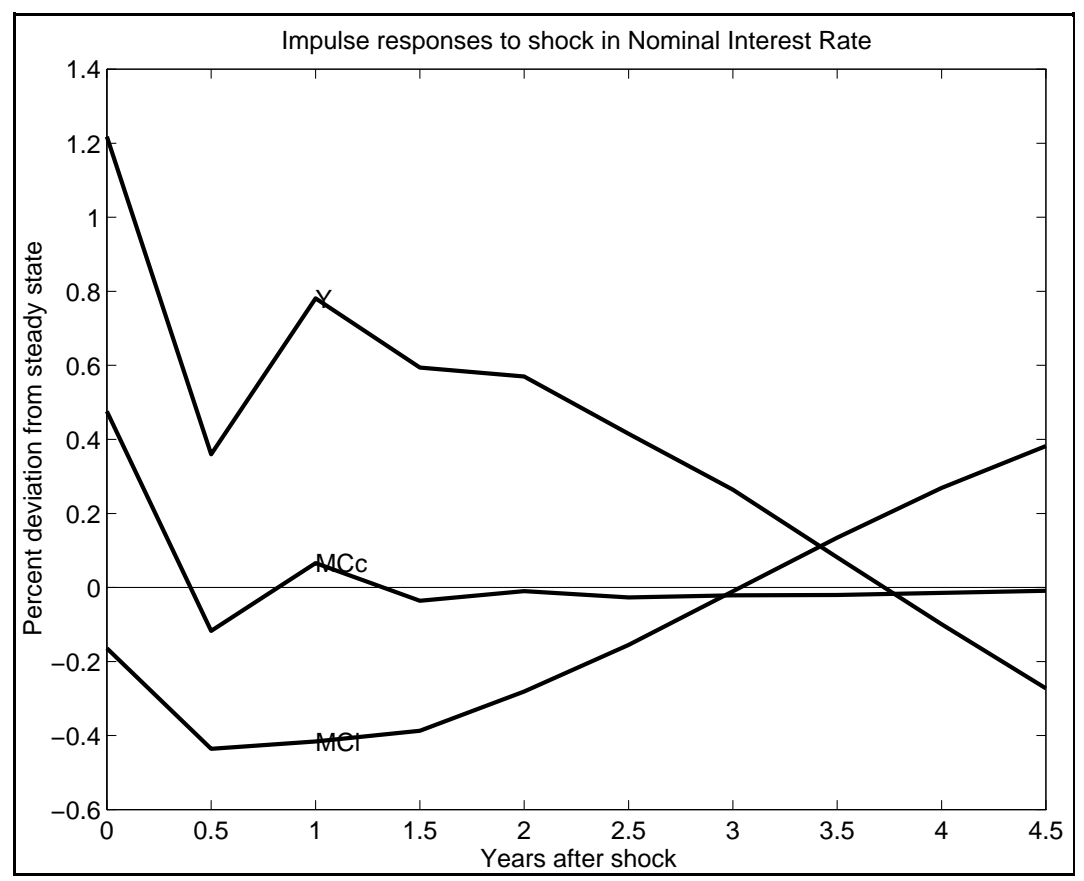

Figure 6: Two Sector Staggered Price Model with $\gamma=1.20$

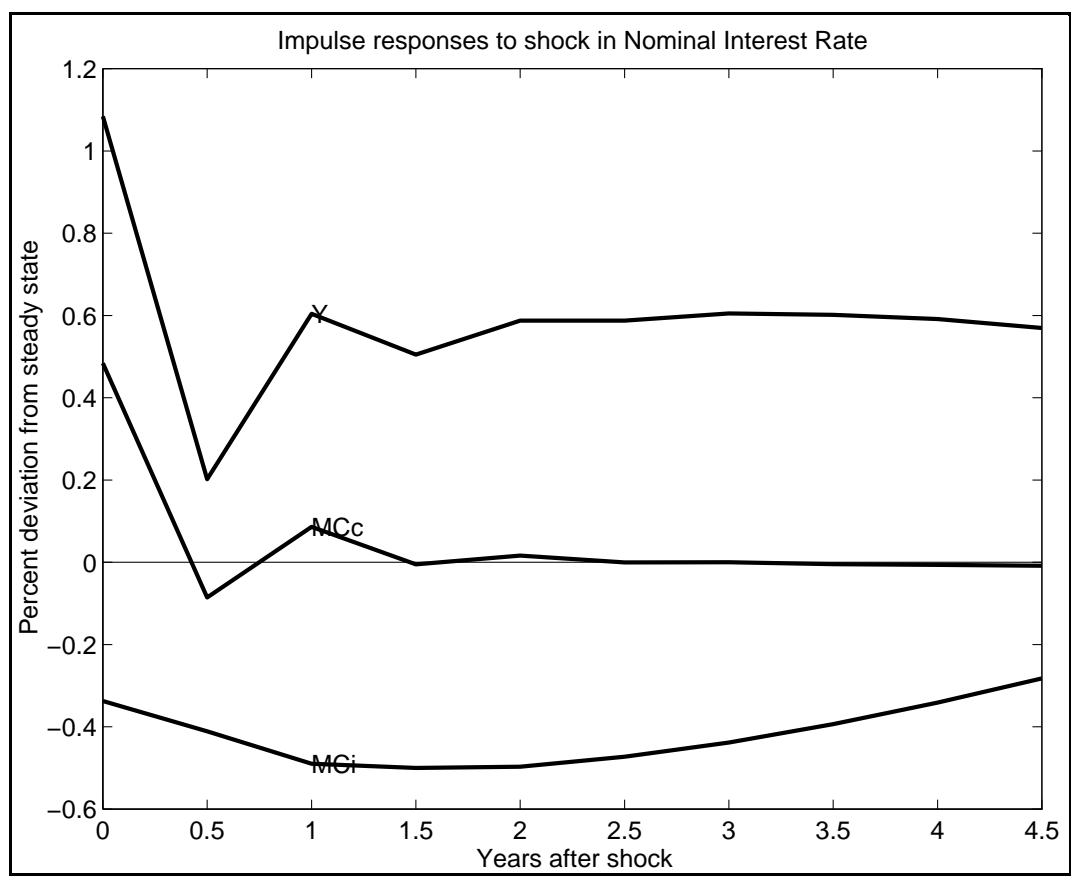


Figure 7: Countercyclical Markup Model with $\mu=1.4$ and $1 / \xi=1.4$

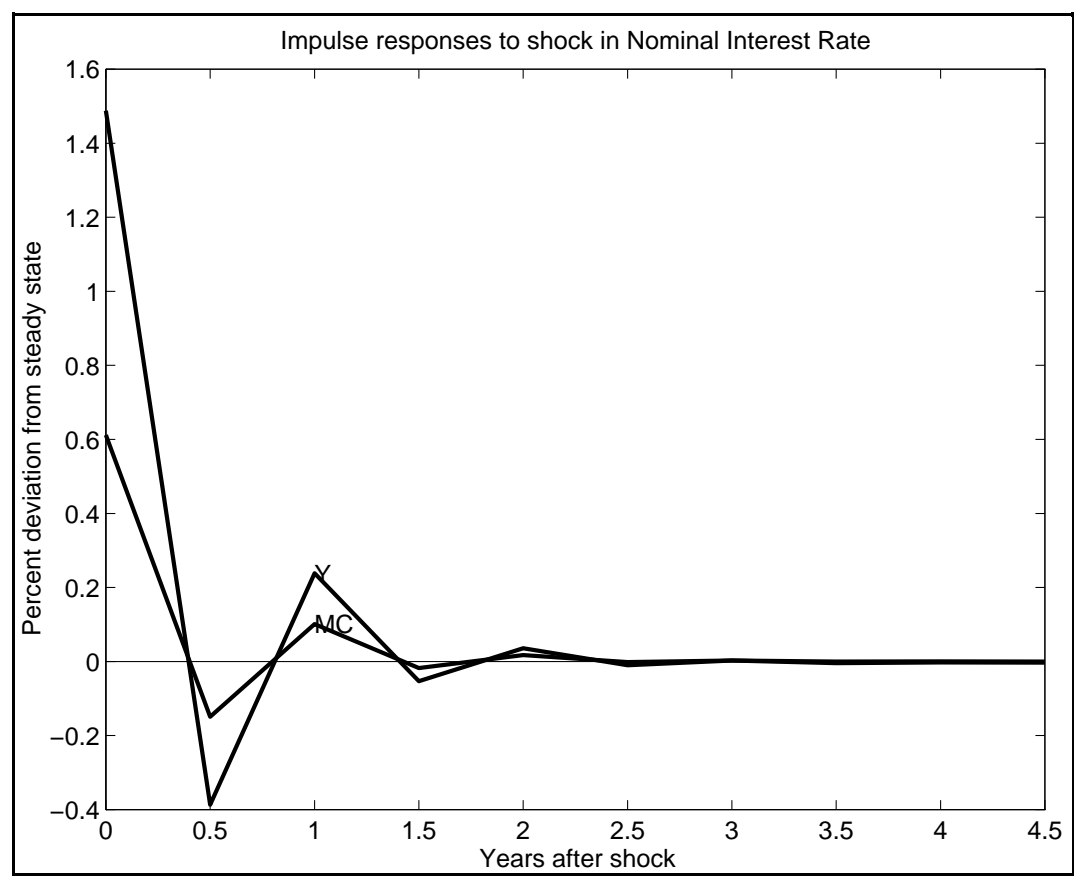

Figure 8: Countercyclical Markup Model with $\mu=1.4$ and $1 / \xi=1.2$

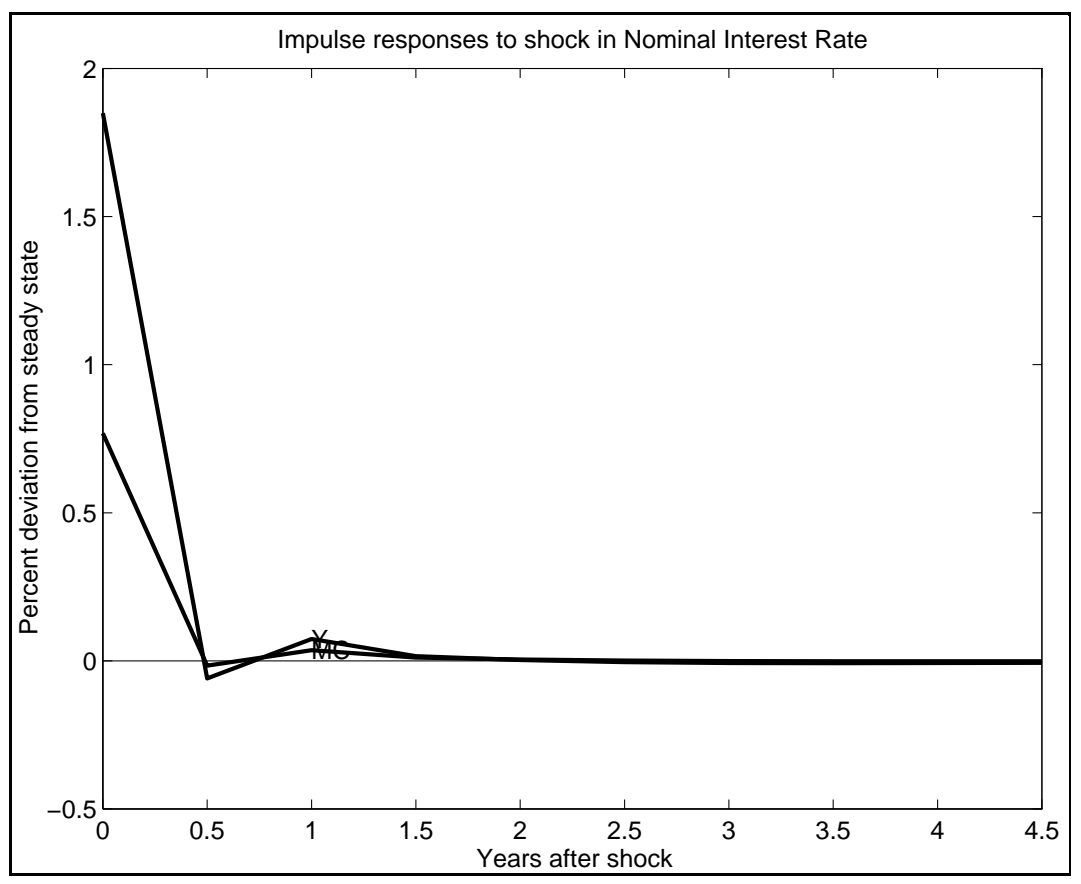


Figure 9: Countercyclical Markup Model with $\mu=1.4$ and $1 / \xi=1.09$

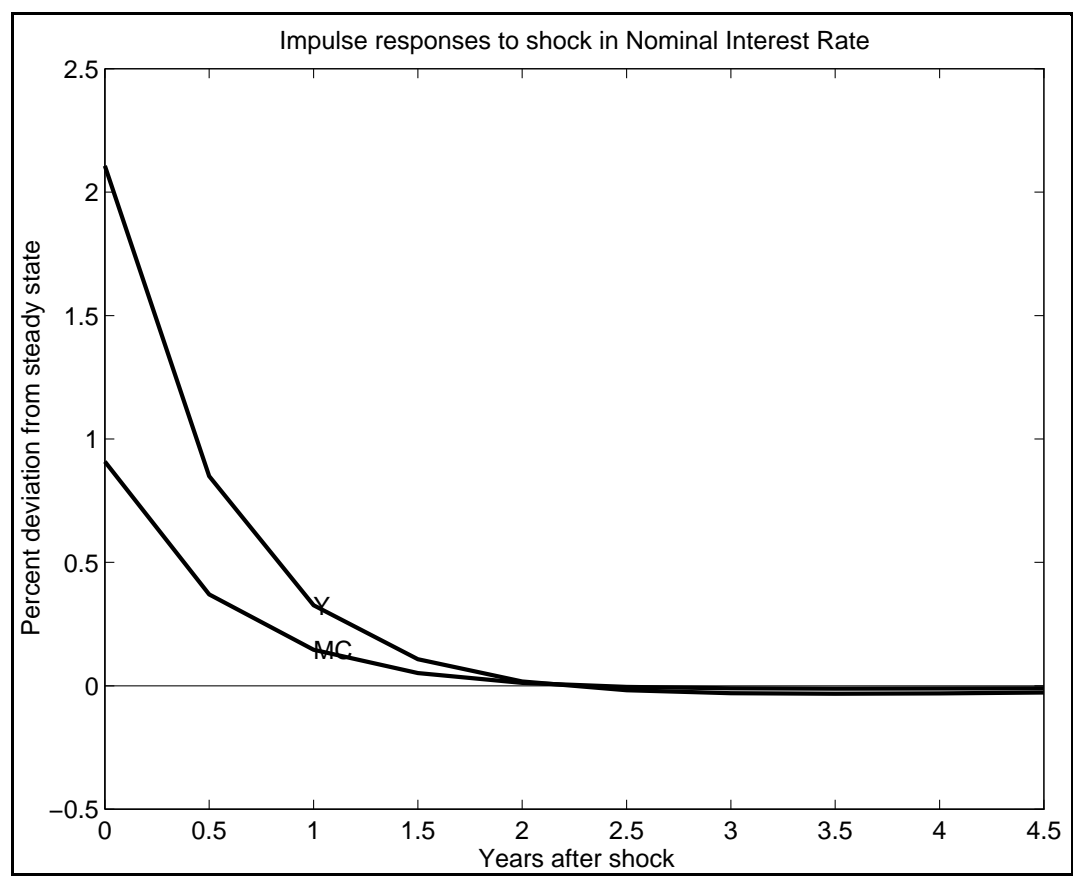




\section{Endnotes}

1. Blanchard and Fischer (1989) contains the clearest definition in line with that in the text (p. 374).

2. Kiley (1997b) compares staggered price setting and the partial adjustment model of Calvo (1983) and Rotemberg $(1982,1987,1996)$.

3. Of course, the parameters of the money demand function still have important implications for the performance of the nominal money supply under a nominal interest rate rule. These implications are not the focus of this study.

4. Note also that individual firm subscripts (i) have been removed, as to a first order log-linear approximation the aggregate and firm specific variables are equal. See footnote 7 below.

5. Blanchard and Fischer (1989), chapter 8, and Chari, Kehoe, and McGrattan (1996).

6. Of course, $b$ cannot equal zero in the base case of the optimizing IS/LM model considered above. However, several modifications of the model would lead to $b=0$. For example, if one abandons preferences consistent with steady state growth and adopts preferences with zero income effects on labor supply such as $\log \left(\mathrm{C}-\mathrm{N}^{1+\mathrm{s}} /(1+\mathrm{s})\right)$, the labor supply equation (2.2) becomes $\mathrm{w}=\mathrm{sn}$, and $\mathrm{b}=0$ under constant returns and infinitely elastic labor supply ( $\mathrm{s}=0$ ). Chari, Kehoe, and McGrattan (1996) consider preferences without income effects as a source of increasing the Taylor contract multiplier, and conclude that the modification does not improve the performance of staggered price setting; I simply note this as a possibility, and will offer alternative modifications of the model to lower $\mathrm{b}$ in subsequent sections.

7. Specifically, in the neighborhood of the symmetric steady state, $\left.\ln \left[\int a \gamma \mathrm{MC}_{\mathrm{it}} \mathrm{Y}_{\mathrm{il}} / \mathrm{K}_{\mathrm{it}} \mathrm{di}\right] \approx \ln (\mathrm{a} \gamma)+\mathrm{mc}_{\mathrm{t}}+\mathrm{y}_{\mathrm{t}}+\mathrm{k}_{\mathrm{t}}\right]$, where $\mathrm{y}_{\mathrm{t}}=\int \ln \mathrm{Y}_{\mathrm{it}} \mathrm{di}$, etc. Note also that the definition of aggregate output from the final goods section also equals this version of $\mathrm{Y}$, to a first order $\log$-linear approximation (i.e., $\mathrm{y}_{\mathrm{t}}=\int \ln \mathrm{Y}_{\mathrm{it}} \mathrm{di} \approx \ln \mathrm{Y}_{\mathrm{t}}=\ln \left[\int \mathrm{Y}_{\mathrm{it}}{ }^{\theta} \mathrm{di}\right]^{1 / \theta} \approx \ln \int \mathrm{Y}_{\mathrm{it}} \mathrm{di}$ ).

8. Rotemberg and Woodford (1997) also discuss the attractiveness of nominal interest rate rules both for realism and because of uncertainty over the form of money demand. Of course, the specification of money demand is important for the behavior of the nominal money supply under a nominal interest rate rule.

9. The quadratic determinantal method of Binder and Pesaran (1995) is used to solve the model.

10. The impulse responses are generated with the package of Uhlig (1995).

11. Dynamic general equilibrium models with sticky prices have recently emphasized the partial adjustment model of sticky prices, as in Goodriend and King (1997), Hairault and Portier (1993), Ireland (1996), Kim (1996), King and Watson (1996), King and Wolman (1996), Rotemberg and Woodford (1997), Woodford (1996), and Yun (1996). Calvo (1983) and Roberts (1995) argue that partial adjustment provides a good approximation to models with staggering, but this is not true in DGE models as typically parameterized because partial adjustment assumes persistence, whereas persistence only arises under staggering when "real rigidities" as defined in this paper are present. See Kiley (1997b).

12. Rotemberg and Woodford (1995) and Schmitt-Grohe (1997) also emphasize that countercyclical markups are an alternative to the increasing returns method of generating sunspots. Chari, Kehoe, and McGrattan (1996) try to generate persistence in a staggered price setting model through countercyclical markups, but they use a method that does not generate sunspot fluctuations under price flexibility, and hence fail to impart sufficient "real 
rigidity" to the economy to succeed in generating persistence.

13. This section's final goods technologies therefore differ from the previous section's in that intermediate goods are not sector specific and the elasticities of substitution between intermediate goods are different in the consumption and investment final goods technologies.

14. Increasing returns are not necessary for persistence under staggered price setting (or sunspots under price flexibility); the fixed costs exist solely to eliminate steady state profits. 